\title{
The Effect of Information Communication Technology and Financial Innovation on Performance on Nigerian Commercial Banks $(2001$ - 2013)
}

\author{
Okonkwo Ikeotuonye Victor, PhD, Obinozie, Henry Ebuka, Echekoba F N \\ Department of Banking and Finance, Nnamdi Azikiwe University, Awka.
}

\begin{abstract}
This study examined the Impact of Information and Communication Technology and financial innovation on the performance of commercial banks in Nigeria, using conveniently selected eleven Commercial Banks in the country. The study used the banks' annual data and Central Bank of Nigeria facts book over the period 2001 to 2013. The study applied ordinary least square (OLS) in its analysis to ascertain the impact of E-Banking services and ATM on the performance of commercial banks in Nigeria. The findings of the study indicate that an increase in banks' profitability performance increases commercial banks' Return on Equity (ROE). Investments in e banking services and ATMs do not really improve banks' performance. The study recommends among other things that more emphasis should be on corporate governance and policies that will increase proper and efficient utilization of financial innovation gadgets rather than simply acquiring additional investments.
\end{abstract}

Keywords: e-banking, Information Communication Technology, and Automated Teller machines

\section{INTRODUCTION}

The importance of Information and Communication Technology (ICT) and Innovations in banking system cannot be over emphasized. An ICT innovation has become an indispensable tool to improve the human lives and connect the nations of the world. The last decade has seen ICT dramatically transforming the world, enabling Banking innovations and productivity increases; connecting people and communities; improving standards of living and creating employment opportunities across the globe.

Information and Communication Technology has become global tool for any Banking system to reach global markets. Thus every Banking system must be ICT compliance in order to survive in global competitive environment. The introduction of ICT has changed manual and traditional forms of doing business. The use of sophisticated technology based on automation and interconnection of computers and other electronic devices are becoming the norm rather than exception. For instance, ledger books, paper invoice, printed materials and business trips are being replaced with online billing and payments, elaborate website with product information and real-time teleconferencing across continents and time zones (Ojokuku and Sajuyigbe, 2012).

Ovia (2001) observes that the Banking system has moved into an era of menu-driven ultra-robust specialized software programmes called Banking system applications and these applications can carry out virtually all Banking system functions relying heavily on information collection, storage, processing and transfer. Similarly, Woherem and Adeogri (2000) rightly says that only banking systems that overhaul the whole of their payment and delivery systems and apply Information Communication Technology (ICT) to their operations are likely to survive and prosper in the new millennium. Banking system should therefore re-examine their service and delivery systems in order to properly position themselves within the framework of the dictates of the dynamism of information and communication technology. The advancement in ICT has played an important role in improving service delivery standards in the financial system like the banking industry (Abubakar and Rasmaini 2012). This has allowed for banking innovation and financial innovation.

Banking innovation is the unanticipated improvement in the array of Banking products and instruments that are stimulated by unexpected change in customer needs and preferences, tax policy, technology and regulatory impulses (Bhattacharyya \& Nanda, 2000). The developments in the Banking sector have not only led to the increase in the number of Banking institutions, but also the development in level of sophistication with new payment systems and asset alternatives to holding money. This has resulted mainly from technological advancement and increase in competition as the number of institutions increase. Developments in payment systems have started to create close substitutes for hard currency, thus affecting a core part of banking.

Financial innovation in the banking industry has been spurred on by the forces described by Noyer (2007) particularly in terms of new distribution channel systems, such as internet and mobile banking. As the industry has provided more ways for consumers to access their accounts, they have added significant costs to each institution. Banks are therefore considering new ways to drive revenue through their distribution system among which is the drive to increase the customer share of wallet. The share of wallet is the portion of a customer's entire Banking relationship that any particular bank has with the customer.

Akin to ICT is the concept of globalization. The world is seen as a global village which turned the markets and economies in like manner. Globalization has caused intense competition in the banking industry, 
worldwide (Nzotta and Okereke, 2009 and Thiel, 2001). The phenomenon called globalization has significantly intensified competition in the banking sector in three particular aspects viz: banks face pressures from a wide and diverse range of competitors; the regulatory environment has become less protective of the banking sector; and competition has become global in nature (Abdulsalam, 2006).

In order to tap the potential benefits of ICT and Banking innovation, Banks deploy ICT based banking products and services such as automated teller machine (ATM), internet banking, mobile banking solutions, point of sale terminals, computerized Banking accounting and reporting, human resources solution among others. In spite of these, there is a debate about whether and how the ICT adoption improves commercial banks performance especially in Nigeria. This study aims to answer determine the impact of E-banking services on banks Return on Equity; and the effect of Automatic Teller Machine (ATM) on commercial Banks Net profit. The formulated hypotheses formulated in null format are: E- banking services has no positive and significant impact on the performance of commercial banks in Nigeria; and Automatic Teller Machine (ATM) has no positive and significant effect on the performance of commercial banks in Nigeria.

This work is further divided into seven sections: the introduction; conceptual framework; theoretical framework; empirical review; research methodology; data presentation and analysis; and summary of findings, conclusion and recommendations.

\section{CONCEPTUAL FRAMEWORK}

According to Wikipedia (the free encyclopaedia), Banking innovation refers to the creating and marketing of new types of securities. Questions may arise, why does Banking innovation occur? Economic theory has much to say about what types of securities should exist, and why some may not exist (why some market should be incomplete) but little to say about why new types of securities should come into existence. Some types of financial innovation are driven by improvement in computer and telecommunication technology. For example, Paul Volcker suggested that for most people, the creation of the ATM was a greater Banking innovation than asset backed securitization. Other types of financial innovation affecting the payment system include credit and debit cards and online payment system like paypal (e- banking service). These types of innovations are notable because they reduce transaction costs. Households need keep lower cash-in-advance constraints then these kinds of Banking innovation can contribute to greater efficiency and performance.

Microsoft Encarta 2009 defined information and communication technology as the processing of data via computer: the use of technologies from computing, electronics, and telecommunications to process and distribute information in digital and other forms. Information technology combines the technology of computers and communications to provide information processing services throughout the office or around the world. Sajuyigbe and Alabi, (2012) posited that ICTs encompass technologies that can process different kinds of information (audio, video, text, and data), and facilitate different forms of communications among human agents, and among information systems. It consists of harnessing electronic technology for the information needs of businesses at all levels. In addition, Longley and Shain (1992) defines information and communication technology as the acquisition, processing, storage and dissemination of vocal, pictorial, textual and numerical information by a micro-electronic based combination for computing and telecommunication. An information system (IS) is a group of formal process that together collects, retrieve, process, store and disseminate information for the purpose of facilitating planning, control, coordination and decision making in organizations. Information and communication technology on the other hand provides the technical solutions identified in the (IS) information system; including the networks, hardware and software (Accad, 2009).

The use of information and communication technology in banking operations is called electronic banking. Ovia (2001) says that Electronic banking is a product of e-commerce in the field of banking and Banking services. In what can be describe as Business-to-consumer (B2C) domain for balance enquiry, request for cheque books, recording, stop payment instruction, balance transfer instruction, account opening and other forms of traditional banking services. Banks are also offering payment services on behalf of their customers who shop in different e-shops. The use of information technology in banking operations is called electronic banking.

Josiah and Nancy, (2012) observed that there are positive impacts of e-banking on bank turnover and profitability and to a lesser extent on employment, most notably when e-commerce is part of larger business strategies of bank. The use of e-banking can contribute to improved bank performance, in terms of increased market share, expanded product range, customized products and better response to client demand. Only banks that use their technology resources effectively have the opportunity to secure real competitive advantage in this fast changing industry through real product or service differentiation.

Information and Communication Technologies (ICTs) refers to technologies people use to share, distribute, and gather information, and to communicate through computers and computer networks (Laudon and Laudon, 2001). ICTs can be described as a complex varied set of goods, applications and services used for producing, distributing, processing, transforming information (including) telecoms, TV and radio broadcasting, hardware and software, computer services and electronic media (Laudon and Laudon; 2001). ICTs represent a 
cluster of associated technologies defined by their functional usage in information access and communication, of which one embodiment is the Internet.

Ojokuku and Sajuyigbe (2012) identified the following Information and Communication Technology banking products:

Automated Teller Machine (ATM): An ATM device allows a bank customer to withdraw cash from his account via a cash dispenser (Machine), and the account is debited immediately. A fundamental advantage is that it needs not to be located within the banking premises. It is usually in stores, shopping malls, fuel stations etc. It saves customers time in service delivery as alternative to queuing in bank halls, customers can invest such time saved into other productive activities. ATMs are a cost-efficient way of yielding higher productivity as they achieve higher productivity per period of time than human tellers.

The Card System: The card system is a unique electronic payment type. The smart cards are plastic devices with embedded integrated circuit being used for settlement of financial obligations. The power of cards lies in their sophistication and acceptability to store and manipulate data, and handle multiple applications on one card securely. Depending on the sophistication, it can be used as a Credit Card, Debit Card and ATM (Automated Teller Machine) card.

Point of Sale (POS) terminals: POS terminals handle cheque verifications, credit authorization, cash deposit and withdrawal, and cash payment. This enhances electronic fund transfer at the point of sale (EFTPOS). EFTPOS enables a customer's account to be debited immediately with the cost of purchase in an outlet such as a supermarket or petrol station. It consists of the accumulation of electronic payment messages by the retailer, which are subsequently passed on to appropriate institutions for processing. The purchase price is debited on the buyer's account and credited on the seller's account.

A credit card: This is a payment card issued to users as a system of payment. It allows the cardholder to pay for goods and services based on the holder's promise to pay for them. The issuer of the card creates a revolving account and grants a line of credit to the consumer(or the user) from which the user can borrow money for payment to a merchant or as a cash advance to the user.

A debit card: This is also known as a bank card or check card is a plastic payment card that provides the cardholder electronic access to his or her bank account(s) at a Banking institution. Some cards have a stored value with which a payment is made, while most relay a message to the cardholder's bank to withdraw funds from a payee's designated bank account. Online debit cards require electronic authorization of every transaction and the debits are reflected in the user's account immediately. The transaction may be additionally secured with the personal identification number (PIN) authentication system; some online cards require such authentication for every transaction, essentially becoming enhanced automatic teller machine (ATM) cards.

Mobile Banking: Mobile Banking refers to provision and availing of banking - and Banking services with the help of mobile telecommunication devices. The scope of offered services may include facilities to conduct bank and stock market transactions, to administer accounts and to access customized information.

\section{THEORETICAL FRAMEWORK}

A modified form of Solow's (1957) neoclassical growth model is adopted in this work. Essentially, aggregate output (Y) is modelled as a simple function of IT capital services (KIT), other capital services (KOTH), include labour (L), and a multifactor productivity term (MFP). Technological change is embodied in the MFP variable. A number of neoclassical assumptions are imposed, including perfect competition, constant returns to scale, no adjustment costs, equal returns to all types of capital, and Hicks-neutral technological change. The growth in labour productivity is given by: $\quad \Delta(\mathrm{Y} / \mathrm{L})=\alpha_{1} \Delta(\mathrm{KIT} / \mathrm{L})+\alpha_{2} \Delta(\mathrm{KOTH} / \mathrm{L})+\Delta \mathrm{MFP}$

Where $\Delta$ denotes a growth rate, and

$\alpha$ represents the income shares.

Technological progress is measured by the Solow residual or $\triangle \mathrm{MFP}$.

Porter (1985) explains that competitive advantage grows fundamentally out of the value a firm is able to create for its buyers that exceeds the firm's cost of creating it. In this sense, value is what buyers are willing to pay, and superior value stems from offering lower prices than competitive price for equivalent benefits or providing unique benefits that more than offset a higher price. To achieve sustainable profit, therefore, a firm needs sustainable advantage, in either cost or differentiation (Porter, 1985). These two basic types of source of competitive advantage combined with the scope of the firm's activity lead to three known generic strategies cost leadership, differentiation strategy and focus strategy - for achieving above - average performance in an industry. This research work adopted Porter (1985) competitive advantage grows model.

\section{EMPIRICAL REVEIW}

Irechukwu (2000) lists some banking services that have been revolutionized through the use of ICT as including account opening, customer account mandate, and transaction processing and recording. ICT products in use in the banking industry include automated teller machine, smart cards, telephone banking, MICR, electronic funds 
transfer, electronic data interchange, electronic home and office banking (Akpan, 2008 and Johnson, 2005). Agboola (2001) studied the impact of computer automation on the banking services in Lagos and discovered that electronic banking has tremendously improved the services of some banks to their customers in Lagos. AragbaAkpore (1998) investigated on the application of information technology in Nigerian banks and pointed out that IT is becoming the backbone of banks' services regeneration in Nigeria. He cited the Diamond Integrated Banking Services (DIBS) of the Diamond Bank Limited and electronic smart card accounts (ESCA) of All States Bank Limited as efforts geared towards creating sophistication in the banking sector. Ovia (2000) discovered that banking in Nigeria has increasingly depended on the deployment of information technology and that the IT budget for banking is by far larger than that of any other industry in Nigeria. He contended that the on-line system has facilitated internet banking in Nigeria as evidenced in some of them launching websites. He found also that banks now offer customers the flexibility of operating an account in any branch irrespective of which branch the account is domiciled. Woherem (1997) discovered that since 1980s Nigerian banks have performed better in their investment profile and use of ICT systems, then the rest of the industrial sector of the economy.

Acharya, Kagan, Lingam, and Gray (2008) examines the impact of web design features of a community banks' performance using a sample of 55 community banks with online services in the five mid western states of the United States of America. The authors utilized both primary and secondary data by applying multiple regression models. The results show that banks with higher usability of ICT perform significantly better than those with low ICT usability. Egland, Frust, Nolle and Robertson (1998) conduct a study and found no evidence of major differences in performance of electronic banking in the US subject to two caveats:

1. This result may not be the case for all the banks.

2. Such result is open to change over time as banks become more severe in the use of innovation.

Sullivan (2009) also found no systematic evidence that multi-channel banks in the $10^{\text {th }}$ Federal Reserve District were either helped or harmed by having transactional web sites. These finding were among the previous findings of Sathye (2005), for the credit unions in Australian banks for the period of 1997 to 2001, shows that electronic banking has not proved to be a yard stick for performance enhancing tool. According to Haq (2005) banks' existence depend on their ability to achieve economies of scale in minimizing asymmetry of information between savers and borrowers.

\section{RESEARCH METHODOLOGY}

The data were extracted from the banks' annual reports and CBN Factbooks covering the period $2001-2013$. The data comprises of net profits, total assets, return of equity, ATM machines and e- banking services of eleven selected commercial banks in Nigeria, namely; Access Bank Plc., Diamond Bank Plc,, Eco Bank Plc, Fidelity Bank Plc, First Bank of Nigeria Plc, GTbank Plc, Sterling Bank Plc, Union Bank of Nigeria Bank Plc, United Bank for Africa Plc, Wema Bank Plc and Zenith Bank Plc. The variables of interest included net profit, ICT innovation, shareholders' funds, total asset, and return on equity. They were not comprehensively provided by all the banks. Thus, the banks whose data were accessibly were targeted for the purpose of this study.

The variables captured in the model specified in this study were:

Dependent variable: Bank Performance - this variable has often been measured using return on asset (ROA) and return on equity (ROE). Return on asset is defined as net income after tax divided by total assets. This ratio is an indicator of managerial efficiency; it indicates how capable the management of the banks has been converting the bank's assets into net earnings, while return on equity is measured as net income after tax divided by total equity capital. It measures the rate of return to the shareholder. In this study return on equity is our proxy for the bank performance.

Independent variables: The explanatory variables in the model are:

i. $\quad$ Profit after Tax (PAT): This was measured as profits realized by the bank after tax.

ii. $\quad$ ATM: This variable was measured by the number of ATM used by each bank.

iii. $\quad$ E-banking services (ebserv): The total number of e-banking services available in each bank was used.

We therefore states that: $\mathrm{BP}=\mathrm{f}(\mathrm{PAT}, \mathrm{ATM}$, ebserv $)$

$\operatorname{LogBP}=\log \beta_{0}+\log \beta_{1}$ PAT $+\log \beta_{2} A T M+\log \beta_{3}$ ebserv $+\mu$

Where,

$\mathrm{BP}=$ Bank performance

$\beta_{0}=$ Constant parameter

$\mathrm{PAT}=$ Profit after tax

ATM $=$ Number of automated teller machines

ebserv $=$ number of e-banking services

$\mu=$ Error term

Using regression techniques i.e ordinary least square approach, and e-view software, the available data were analysed. The input data from 2001- 2013 are presented in appendix I. Our a priori expectations are shown 
in Table 1

Table 1 A Priori Expectations

\begin{tabular}{|l|c|}
\hline Independent Variables & Expected Signs \\
\hline Net Profit & + \\
\hline ATM & - \\
\hline E-banking services & - \\
\hline
\end{tabular}

DATA PRESENTATION AND ANALYSIS

The least square estimation output data were shown in Table 2.

Table 2 Least Square Estimation

\begin{tabular}{|c|c|c|c|c|c|}
\hline Variable & Coefficient & \multicolumn{2}{|c|}{ Std. Error. } & t- statistics & Prob. \\
\hline EBSERV & 0.166274 & \multicolumn{2}{|c|}{1.079751} & 0.153993 & 0.8778 \\
\hline ATM & -0.012380 & \multicolumn{2}{|c|}{0.018205} & -0.6800037 & 0.4976 \\
\hline PAT & 1.65 & \multicolumn{2}{|c|}{1.95} & 8.441417 & 0.0000 \\
\hline $\mathbf{C}$ & 10.45794 & \multicolumn{2}{|c|}{10.58629} & 0.987876 & 0.3249 \\
\hline \multicolumn{2}{|l|}{ R-Squared } & 0.379986 & \multicolumn{2}{|c|}{ Mean dependent var } & 24.00570 \\
\hline \multicolumn{2}{|c|}{ Adjusted R-Squared } & 0.362014 & \multicolumn{2}{|c|}{ S.D. dependent var } & 79.42834 \\
\hline \multicolumn{2}{|c|}{ S.E of Regression } & 63.44260 & \multicolumn{2}{|c|}{ Akaike info criterion } & 11.17249 \\
\hline \multicolumn{2}{|c|}{ Sum squared residual } & 555445.0 & \multicolumn{2}{|c|}{ Schwardz criterion } & 11.27608 \\
\hline \multicolumn{2}{|c|}{ Log likelihood } & -793.8328 & \multicolumn{2}{|c|}{ Hannan-Quinn criterion } & 11.21458 \\
\hline \multicolumn{2}{|c|}{ F-statistic } & 21.14387 & \multicolumn{2}{|c|}{ Durbin-Watson stat } & 1.488170 \\
\hline
\end{tabular}

Source: Computer analysis using E-View

The analysis shows that the coefficient (0.1662) for E banking services shows a positive influence on banks performance, but it is not statistically significant, this finding indicates that investment in e banking services does not increase commercial banks performance.

The analysis shows that the coefficient (-0.01238) related to ATM's usability is negative and not statistically significant. This finding indicates that the use of ATM's does not enhance commercial banks performance in Nigeria. ATM does not have significant effect on the performance of commercial banks.

Table 3 summarizes the outcome of the model parameters on a priori ground.

Table 3: A Priori Expectations

\begin{tabular}{|l|c|c|l|}
\hline Independent Variables & Expected Signs & Observed Signs & Remarks \\
\hline Net Profit & + & + & Conform \\
\hline ATM & - & - & Conform \\
\hline E-banking services & - & + & Does not conform \\
\hline
\end{tabular}

All the independent variables except E-banking services conformed to economic theory

\section{SUMMARY OF FINDINGS, CONCLUSION AND RECOMMENDATIONS}

The findings are summarized as follows:

i. Banking innovations do no really improve performance in the Nigerian Commercial Banks.

ii. The E banking services shows a positive influence on banks performance, but it is not statistically significant. This finding indicates that investment in e banking services does not necessarily increase commercial banks performance proportionately.

iii. The ATM's usability is negative and not statistically significant. This finding indicates that the use of ATM's does not necessarily influence commercial banks performance in Nigeria. It may result to liability on the side of the host banks.

\section{CONCLUSION}

Investments towards banking innovation do not simply improve commercial banks' performance in Nigeria. Prudent management of banks' fund and increasing customers' base will contribute significantly to the banks' performance.

In addition, profit after tax serve as prime factor indicating commercial banks performance in Nigeria; however, better proxy to measure commercial banks performance are return on equity and return on assets.

\section{RECOMMENDATIONS}

Based on the findings of this study, the following recommendations are postulated:

a. Since the findings of this study indicate that investments in banking innovation do not simply translate to improve commercial banks performance, banks should give emphasis on efficient utilization of the banking innovation or e- banking services equipment such as credit and electronic cards to pay at retail 
outlets, points of sales (POS), phone banking, electronic payment debit, cash withdrawal machines that becomes Automated Teller Machines (ATM), home banking, internet banking, mobile banking, personal digital assistant banking rather than purchase of additional machines.

b. For commercial banks in Nigeria to actually reap the benefit of banking innovation more campaigns and orientation of clients need to be pursued to create awareness for them to patronize the facilities. Acceptance of these facilities will consolidate the gains from investing in them.

\section{REFERENCES}

Abdulsalam, O. D. (2006). Impact of Information Technology on Corporate Performance: A Study of selected Banks in Nigeria. A Ph.D. Thesis submitted to the Postgraduate School, Usmanu Danfodiyo University, Sokoto.

Abubakar, A. \& Rasmaini B. T. (2012). The impact of ICT on banks' performance and customer service delivery in the banking industry. International Journal Latest Trends Finance Economic Science, $2,1$.

Accad, M. (2009). The future of electronic banking in Nigeria. The role of the internet, US embossing sponsored e-week 2009.

Acharya, V. V. \& Yorulmazer, T. (2008). Information Contagion and Bank Herding. Journal of Money, Credit and Banking, Volume 40, number 1: February.

Acharya, R. N., Kagan, A. Lingam, S. R. \& Gray, K. (2008). Impact of Website Usability on Performance: A Heuristic Evaluation of Community Bank Homepage Implementation, Journal of Business \& Economics Research, Volume 6, number 6: June.

Agboola, A. A. (2001). Impact of Electronic Banking on Customer Services in Lagos, Nigeria, Ife Journal of Economics and Finance, Vol. 5, Nos. 1\&2.

Akpan, N. (2008). E-payment solutions: Are Banks getting it right? Business day; Wednesday, February 27th.

Aragba-Akpore, S. (1998). The Backbone of Banks' Service Regeneration, Moneywatch, July 22, p. 23.

Berger, A. N. (2003). The Economic Effects of Technological Progress: Evidence from the Banking Industry, Journal of Money, Credit, Banking, Volume 35, number 2: Pp. 141 - 176.

Bhattacharyya, S. \& Nanda, V. K. (2000). Client discretion, switching costs and Banking innovation. Review of Banking Studies, Vol. 13, PP1101-1127.

Egland, K. L., Furst, K., Nolle, D., E. \& Robertson, D. (1998). Banking over the Internet. Quarterly Journal of Office of Comptroller of the Currency. 17(4).

Haq, M. F. (2005). "The Role of information systems in Islamic Banking: An Ethnographic study" University of London: London.

Irechukwu, G., (2000). Enhancing the Performance of Banking Operations Through Appropriate Information Technology, In: Information Technology in Nigerian Banking Industry, Spectrum Books, Ibadan, Pp. 63-78.

Josiah, A. \& Nancy, K. (2012). The relationship between electronic banking and Banking performance among commercial banks in Kenya. Journal of finance and investment analysis. Vol.1, No 3 Pp 99-103.

Johnson, M. (2005). Overview of Electronic Payment Systems in Nigeria: Strategic and Technical Issues, Central Bank of Nigeria Bullion, Volume 29, number 2: April/June.

Laudon, D. P. \& Laudon, J. P. (2001). Management Information Systems: Organization and Technology in the Network Enterprises, 4th ed. Prentice Hall International in. U.S. New American Corporation, New York: Dutton.

Longley, L. \& Shain, M. (1989). Dictionary of Information Technology, The Macmillan Press Ltd, London.

Malhotra, P. \& Singh, B. (2009). The Impact of Internet Banking on Bank Performance and Risk: The Indian Experience, Eurasian Journal of Business and Economics, Volume 2, number 4: Pp. 43 - 62.

Nzotta, S. M. \& Okereke, E. J. (2009). Banking Deepening and Economic Development of Nigeria: An Empirical Investigation, African Journal of Accounting, Economics, Finance and Banking Research, Volume 5, number 5.

Ojokuku, R. M. \& Sajuyigbe, A. S. (2012).The Impact of Electronic Banking on Human Resources Performance in the Nigerian Banking Industry. International Journal of Economic Development Research and Investment Vol. 3, No 2.Pp 61-69.

Ovia, J. (2001). Internet Banking: Practices and Potentials in Nigeria. A paper presented at a seminar organized by the Institute of Chartered Accountants of Nigeria (ICAN) Lagos Sheraton Hotel \& Towers, Ikeja. September 05.

Sajuyigbe, A. S. \& Alabi, E., (2012). Impact of information and Communication Technology in selected Small and Medium Enterprises in Osogbo metropolis, Nigeria. Journal of school of communication and information technology, Federal Polytechnic, Offa. Vol. 3 No.1Pp 183 -188.

Saythe, M. (2005). The Impact of internet banking on Performance and Risk profile: Evidence from Australian Credit Unions. Journal of Banking Regulation, Vol. 6, pp 163 - 174. 
Sullivan, R. J. (2000). How has the adoption of internet Banking affected performance and Risk at Banks? A look at internet Banking in the $10^{\text {th }}$ Federal Reserve District, Federal Reserve Bank of Kansas City Banking industry Perspective, pp. $1-16$.

Thiel, M. (2001). Finance and Economic Growth: A Review of Theory and the Available Evidence, No. 158, July. http://europs.eu.int/economy_finance.

Woherem, E. \& Adeogri, D. (2000).The Telephone and Computer in banking: Constraints and challenges of information technology in Nigerian Banking Industry. Ibadan: Spectrum Books, pp 94-97.

Woherem, E. W. (1997). Information Technology in the Nigerian Banking Industry, Spectrum, Ibadan.

Woherem, E. W. (2000). Information Technology in the Nigerian Banking Industry, Spectrum, Ibadan.

Appendix I Input data: ATM, Profit after tax, Return on equity and E-banking service (2001 to 2013$)$

\begin{tabular}{|c|c|c|c|c|c|c|c|}
\hline BANK & BID & YEAR & S.F & PAT(Naira) & ATM & ebserv & ROE (\%) \\
\hline ACCESS & 1 & 2001 & 919493000 & 77743000 & 0 & 5 & 0.08455 \\
\hline ACCESS & 1 & 2002 & 1343704 & -55245000 & 0 & 5 & -41.114 \\
\hline ACCESS & 1 & 2003 & 2365356 & 556573000 & 0 & 5 & 235.302 \\
\hline ACCESS & 1 & 2004 & 2702830 & 637473000 & 0 & 5 & 235.8539 \\
\hline ACCESS & 1 & 2005 & 14071324 & 501515000 & 0 & 6 & 34.64092 \\
\hline ACCESS & 1 & 2006 & 28893886 & 737149000 & 34 & 6 & 25.51228 \\
\hline ACCESS & 1 & 2007 & 28384891 & 6083439 & 71 & 6 & 0.21432 \\
\hline ACCESS & 1 & 2008 & 171860665 & 16056464 & 95 & 7 & 0.093427 \\
\hline ACCESS & 1 & 2009 & 185188124 & 20814216 & 154 & 7 & 0.112395 \\
\hline ACCESS & 1 & 2010 & 175370457 & 11068121 & 190 & 7 & 0.063113 \\
\hline ACCESS & 1 & 2011 & 197042209 & 16708255 & 305 & 9 & 0.084795 \\
\hline ACCESS & 1 & 2012 & 186789000 & 174543656 & 481 & 11 & 0.093443 \\
\hline ACCESS & 1 & 2013 & 17250000 & 19654421 & 502 & 13 & 1.139387 \\
\hline DIAMOND & 2 & 2001 & 47372580 & 1689618 & 25 & 4 & 0.035667 \\
\hline DIAMOND & 2 & 2002 & 53003546 & 1478175 & 25 & 4 & 0.027888 \\
\hline DIAMOND & 2 & 2003 & 1152663000 & 65776000 & 35 & 4 & 0.57066 \\
\hline DIAMOND & 2 & 2004 & 883414000 & 903411000 & 41 & 4 & 1.022636 \\
\hline DIAMOND & 2 & 2005 & 2510279 & 2509810 & 50 & 4 & 0.999813 \\
\hline DIAMOND & 2 & 2006 & 222833154 & 3977059 & 150 & 4 & 0.017848 \\
\hline DIAMOND & 2 & 2007 & 320419399 & 7086770 & 164 & 4 & 0.022117 \\
\hline DIAMOND & 2 & 2008 & 62566918 & 12821074 & 165 & 4 & 0.020492 \\
\hline DIAMOND & 2 & 2009 & 650757117 & -8174413 & 180 & 4 & -0.01256 \\
\hline DIAMOND & 2 & 2010 & 6522455 & 548402560 & 180 & 4 & 84.07916 \\
\hline DIAMOND & 2 & 2011 & -22187848 & 722965977 & 180 & 4 & -32.5839 \\
\hline DIAMOND & 2 & 2012 & 326111000 & 726112330 & 180 & 4 & 2.22658 \\
\hline DIAMOND & 2 & 2013 & 138850000 & 914663220 & 180 & 4 & 6.58742 \\
\hline ECO & 3 & 2001 & 2522540 & 716071000 & 0 & 4 & 283.869 \\
\hline $\mathrm{ECO}$ & 3 & 2002 & 2945733 & 553725000 & 0 & 4 & 187.9753 \\
\hline ECO & 3 & 2003 & 3518887 & 816815000 & 0 & 4 & 232.1231 \\
\hline ECO & 3 & 2004 & 4413327 & 854439000 & 0 & 4 & 193.6043 \\
\hline ECO & 3 & 2005 & 25762863 & 1368174 & 0 & 4 & 0.053106 \\
\hline ECO & 3 & 2006 & 132091706 & 3558591 & 52 & 4 & 0.02694 \\
\hline ECO & 3 & 2007 & 311395894 & 7449777 & 104 & 4 & 0.023924 \\
\hline ECO & 3 & 2008 & 432466245 & 2130461 & 163 & 4 & 0.004926 \\
\hline ECO & 3 & 2009 & 355662000 & -4588000 & 185 & 4 & -0.0129 \\
\hline
\end{tabular}

KEYS: S.F: Shareholders' fund; PAT: Profit after tax; ATM: Number of automated teller machine; ROE:

Return on equity; ebserv: Number of banking innovation 
Contd. over leaf

Input data: ATM, Profit after tax, Return on equity and E-banking service (2001 to 2013) contd.

\begin{tabular}{|c|c|c|c|c|c|c|c|}
\hline BANK & BID & YEAR & S.F & PAT(Naira) & ATM & ebserv & ROE (\%) \\
\hline ECO & 3 & 2010 & 206817600 & 21091040 & 191 & 4 & 0.101979 \\
\hline ECO & 3 & 2011 & 233493760 & 33094400 & 191 & 4 & 0.141736 \\
\hline ECO & 3 & 2012 & 206000000 & 454860000 & 196 & 4 & 2.208058 \\
\hline $\mathrm{ECO}$ & 3 & 2013 & 41000000 & 235710000 & 198 & 4 & 0.574902 \\
\hline FIDELITY & 4 & 2001 & 1300533 & 400661000 & 0 & 8 & 308.0745 \\
\hline FIDELITY & 4 & 2002 & 1915211 & 539242000 & 0 & 10 & 281.5575 \\
\hline FIDELITY & 4 & 2003 & 2515423 & 856885000 & 0 & 10 & 340.6524 \\
\hline FIDELITY & 4 & 2004 & 3519624 & 913604000 & 0 & 10 & 259.5743 \\
\hline FIDELITY & 4 & 2005 & 9776922 & 1305854 & 0 & 10 & 0.133565 \\
\hline FIDELITY & 4 & 2006 & 25664717 & 3218617 & 32 & 10 & 0.12541 \\
\hline FIDELITY & 4 & 2007 & 30101287 & 4714283 & 56 & 12 & 0.156614 \\
\hline FIDELITY & 4 & 2008 & 136371740 & 13356301 & 89 & 14 & 0.09794 \\
\hline FIDELITY & 4 & 2009 & 435666000 & 1557000 & 112 & 15 & 0.003574 \\
\hline FIDELITY & 4 & 2010 & 154371740 & 14256301 & 134 & 18 & 0.9235 \\
\hline FIDELITY & 4 & 2011 & 165371740 & 15356421 & 168 & 18 & 0.9286 \\
\hline FIDELITY & 4 & 2012 & 166433223 & 15356422 & 173 & 18 & 0.921514 \\
\hline FIDELITY & 4 & 2013 & 167000000 & 15432113 & 173 & 18 & 0.924079 \\
\hline FIRST & 5 & 2001 & 18170000 & 5066000 & 50 & 5 & 0.278811 \\
\hline FIRST & 5 & 2002 & 19406000 & 4776000 & 65 & 5 & 0.26109 \\
\hline FIRST & 5 & 2003 & 27006000 & 11010000 & 73 & 6 & 0.407687 \\
\hline FIRST & 5 & 2004 & 41605000 & 11483000 & 104 & 8 & 0.276 \\
\hline FIRST & 5 & 2005 & 48726000 & 13234000 & 280 & 10 & 0.2716 \\
\hline FIRST & 5 & 2006 & 64277000 & 17383000 & 650 & 10 & 0.270439 \\
\hline FIRST & 5 & 2007 & 83627000 & 20636000 & 729 & 10 & 0.246762 \\
\hline FIRST & 5 & 2008 & 351854000 & 36679000 & 818 & 10 & 0.104245 \\
\hline FIRST & 5 & 2009 & 337405000 & 12569000 & 904 & 10 & 0.037252 \\
\hline FIRST & 5 & 2010 & 32123000 & 1962444 & 1090 & 16 & 0.061092 \\
\hline FIRST & 5 & 2011 & 47462000 & 2463543 & 1090 & 16 & 0.051906 \\
\hline FIRST & 5 & 2012 & 472432244 & 3231145 & 2310 & 18 & 0.068394 \\
\hline FIRST & 5 & 2013 & 350710000 & 4522556 & 2317 & 18 & 0.128954 \\
\hline G. TRUST & 6 & 2001 & 4026177 & 1503694 & 15 & 13 & 0.373479 \\
\hline G. TRUST & 6 & 2002 & 8016492 & 2187059 & 23 & 13 & 0.27282 \\
\hline G. TRUST & 6 & 2003 & 9638925 & 3144182 & 26 & 15 & 0.326196 \\
\hline G. TRUST & 6 & 2004 & 11754406 & 4125832 & 35 & 15 & 0.351003 \\
\hline G. TRUST & 6 & 2005 & 33643184 & 5433748 & 60 & 17 & 0.161511 \\
\hline G. TRUST & 6 & 2006 & 40549833 & 8590265 & 160 & 18 & 0.211845 \\
\hline
\end{tabular}

Contd. over leaf 
Input data: ATM, Profit after tax, Return on equity and E-banking service (2001 to 2013$)$ contd.

\begin{tabular}{|c|c|c|c|c|c|c|c|}
\hline BANK & BID & YEAR & S.F & PAT(Naira) & ATM & ebserv & ROE $(\%)$ \\
\hline G. TRUST & 6 & 2007 & 47324118 & 13193759 & 170 & 18 & 0.278796 \\
\hline G. TRUST & 6 & 2008 & 160008886 & 21169477 & 185 & 20 & 0.132302 \\
\hline G. TRUST & 6 & 2009 & 1065504345 & 23687567 & 200 & 21 & 0.022231 \\
\hline G. TRUST & 6 & 2010 & 112550545 & 32685776 & 215 & 23 & 0.024599 \\
\hline G. TRUST & 6 & 2011 & 531563000 & 370038000 & 215 & 23 & 0.027806 \\
\hline G. TRUST & 6 & 2012 & 424332700 & 384009800 & 281 & 28 & 0.904973 \\
\hline G. TRUST & 6 & 2013 & 332350000 & 432234500 & 281 & 30 & 1.30054 \\
\hline STERLING & 7 & 2001 & 531563000 & 370038000 & 0 & 5 & 0.6966132 \\
\hline STERLING & 7 & 2002 & 664454000 & 39810000 & 0 & 4 & 0.059914 \\
\hline STERLING & 7 & 2003 & 831688000 & 178923000 & 0 & 4 & 0.215132 \\
\hline STERLING & 7 & 2004 & 1243294 & 1545077 & 0 & 4 & 1.242729 \\
\hline STERLING & 7 & 2005 & 2966726 & -4820558 & 0 & 4 & -1.62487 \\
\hline STERLING & 7 & 2006 & 26319328 & 961645000 & 45 & 4 & 36.5376 \\
\hline STERLING & 7 & 2007 & 26800395 & 620658000 & 50 & 6 & 23.15854 \\
\hline STERLING & 7 & 2008 & 6523153 & 236502923 & 55 & 6 & 36.25592 \\
\hline STERLING & 7 & 2009 & -6660406 & 205640827 & 60 & 6 & -30.8751 \\
\hline STERLING & 7 & 2010 & 4178493 & 259579523 & 68 & 6 & 62.12276 \\
\hline STERLING & 7 & 2011 & 6686473 & 504427737 & 68 & 6 & 75.44003 \\
\hline STERLING & 7 & 2012 & 286489980 & 516534667 & 68 & 6 & 1.802976 \\
\hline STERLING & 7 & 2013 & 321740000 & 540907790 & 68 & 6 & 1.681195 \\
\hline UBA & 8 & 2001 & 9067000 & 1269000 & 15 & 3 & 0.139958 \\
\hline UBA & 8 & 2002 & 10627000 & 1566000 & 23 & 3 & 0.14736 \\
\hline UBA & 8 & 2003 & 14901000 & 3280000 & 32 & 3 & 0.220119 \\
\hline UBA & 8 & 2004 & 19533000 & 4525000 & 32 & 3 & 0.231659 \\
\hline UBA & 8 & 2005 & 19443000 & 4525000 & 42 & 4 & 0.253099 \\
\hline UBA & 8 & 2006 & 48535000 & 11550000 & 83 & 4 & 0.237973 \\
\hline UBA & 8 & 2007 & 167719000 & 21441000 & 112 & 4 & 0.127839 \\
\hline UBA & 8 & 2008 & 1673333 & 40825000 & 142 & 4 & 24.39742 \\
\hline UBA & 8 & 2009 & 1548281 & 2375000 & 182 & 4 & 1.533959 \\
\hline UBA & 8 & 2010 & 2167000 & 1432632 & 253 & 4 & 0.661113 \\
\hline UBA & 8 & 2011 & -16385000 & 1655465 & 340 & 4 & -0.10104 \\
\hline UBA & 8 & 2012 & 132240000 & 1734356 & 344 & 6 & 0.131152 \\
\hline UBA & 8 & 2013 & 259540000 & 1843556 & 348 & 6 & 0.0771032 \\
\hline UNION & 9 & 2001 & 13786000 & 5035000 & 0 & 4 & 0.365226 \\
\hline UNION & 9 & 2002 & 30302000 & 4726000 & 0 & 4 & 0.155963 \\
\hline UNION & 9 & 2003 & 32730000 & 6600000 & 0 & 4 & 0.20165 \\
\hline
\end{tabular}

Contd. over leaf 
Input data: ATM, Profit after tax, Return on equity and E-banking service (2001 to 2013) contd.

\begin{tabular}{|c|c|c|c|c|c|c|c|}
\hline BANK & BID & YEAR & S.F & PAT(Naira) & ATM & ebserv & ROE (\%) \\
\hline UNION & 9 & 2004 & 39732000 & 8341000 & 0 & 4 & 0.209932 \\
\hline UNION & 9 & 2005 & 43215000 & 9783000 & 0 & 7 & 0.22638 \\
\hline UNION & 9 & 2006 & 100500000 & 10802000 & 35 & 7 & 0.107383 \\
\hline UNION & 9 & 2007 & 102706000 & 13329000 & 56 & 7 & 0.129778 \\
\hline UNION & 9 & 2008 & 25739000 & 26855000 & 83 & 7 & 1.043358 \\
\hline UNION & 9 & 2009 & -281173000 & -281373000 & 190 & 7 & 1.009711 \\
\hline UNION & 9 & 2010 & -135894000 & 118016000 & 198 & 7 & -0.86844 \\
\hline UNION & 9 & 2011 & 301173000 & 301173000 & 204 & 7 & 1 \\
\hline UNION & 9 & 2012 & 160087090 & 323469000 & 251 & 7 & 2.020581 \\
\hline UNION & 9 & 2013 & 188000000 & 423227000 & 256 & 7 & 2.251207 \\
\hline WEMA & 10 & 2001 & 619554000 & 675015000 & 0 & 4 & 1.089518 \\
\hline WEMA & 10 & 2002 & 1481667 & 778864000 & 0 & 4 & 525.6674 \\
\hline WEMA & 10 & 2003 & 1477775 & 1527311 & 0 & 4 & 1.033521 \\
\hline WEMA & 10 & 2004 & 967148000 & 1555460 & 0 & 4 & 0.001608 \\
\hline WEMA & 10 & 2005 & 844285000 & 4451625 & 0 & 6 & 0.005273 \\
\hline WEMA & 10 & 2006 & 20540001 & -6601961 & 120 & 6 & -0.32143 \\
\hline WEMA & 10 & 2007 & 25182705 & 2554098 & 150 & 6 & 0.101423 \\
\hline WEMA & 10 & 2008 & 128906575 & -57738739 & 150 & 6 & -0.44791 \\
\hline WEMA & 10 & 2009 & 142785723 & -2094692 & 160 & 6 & -0.01467 \\
\hline WEMA & 10 & 2010 & 203144627 & 16238533 & 168 & 6 & 0.079936 \\
\hline WEMA & 10 & 2011 & 210144627 & 16538533 & 168 & 6 & 0.078701 \\
\hline WEMA & 10 & 2012 & 256708800 & 21564490 & 168 & 6 & 0.840037 \\
\hline WEMA & 10 & 2013 & 410000000 & 464700000 & 168 & 6 & 1.133415 \\
\hline ZENITH & 11 & 2001 & 21044627 & 16538533 & 25 & 5 & 0.424547 \\
\hline ZENITH & 11 & 2002 & 3504013 & 1026658 & 32 & 5 & 0.292995 \\
\hline ZENITH & 11 & 2003 & 4424186 & 1548555 & 53 & 5 & 0.35002 \\
\hline ZENITH & 11 & 2004 & 5190768 & 1548555 & 67 & 5 & 0.298329 \\
\hline ZENITH & 11 & 2005 & 42100031 & 7143266 & 84 & 5 & 0.169674 \\
\hline ZENITH & 11 & 2006 & 100642511 & 11619227 & 102 & 7 & 0.11545 \\
\hline ZENITH & 11 & 2007 & 114586090 & 18779804 & 123 & 7 & 0.163893 \\
\hline ZENITH & 11 & 2008 & 344348245 & 51992239 & 245 & 7 & 0.150987 \\
\hline ZENITH & 11 & 2009 & 335570000 & 20603000 & 267 & 7 & 0.061397 \\
\hline ZENITH & 11 & 2010 & 350414000 & 20603000 & 303 & 7 & 0.009513 \\
\hline ZENITH & 11 & 2011 & 360868000 & 37414000 & 373 & 7 & 0.103678 \\
\hline ZENITH & 11 & 2012 & 462900000 & 100600000 & 384 & 7 & 0.217326 \\
\hline ZENITH & 11 & 2013 & 509300000 & 953200000 & 384 & 7 & 1.871588 \\
\hline
\end{tabular}

Source: Banks' Financial Statement of Various Years and CBN Fact Books 
The IISTE is a pioneer in the Open-Access hosting service and academic event management. The aim of the firm is Accelerating Global Knowledge Sharing.

More information about the firm can be found on the homepage:

http://www.iiste.org

\section{CALL FOR JOURNAL PAPERS}

There are more than 30 peer-reviewed academic journals hosted under the hosting platform.

Prospective authors of journals can find the submission instruction on the following page: http://www.iiste.org/journals/ All the journals articles are available online to the readers all over the world without financial, legal, or technical barriers other than those inseparable from gaining access to the internet itself. Paper version of the journals is also available upon request of readers and authors.

\section{MORE RESOURCES}

Book publication information: http://www.iiste.org/book/

Academic conference: http://www.iiste.org/conference/upcoming-conferences-call-for-paper/

\section{IISTE Knowledge Sharing Partners}

EBSCO, Index Copernicus, Ulrich's Periodicals Directory, JournalTOCS, PKP Open Archives Harvester, Bielefeld Academic Search Engine, Elektronische Zeitschriftenbibliothek EZB, Open J-Gate, OCLC WorldCat, Universe Digtial Library, NewJour, Google Scholar

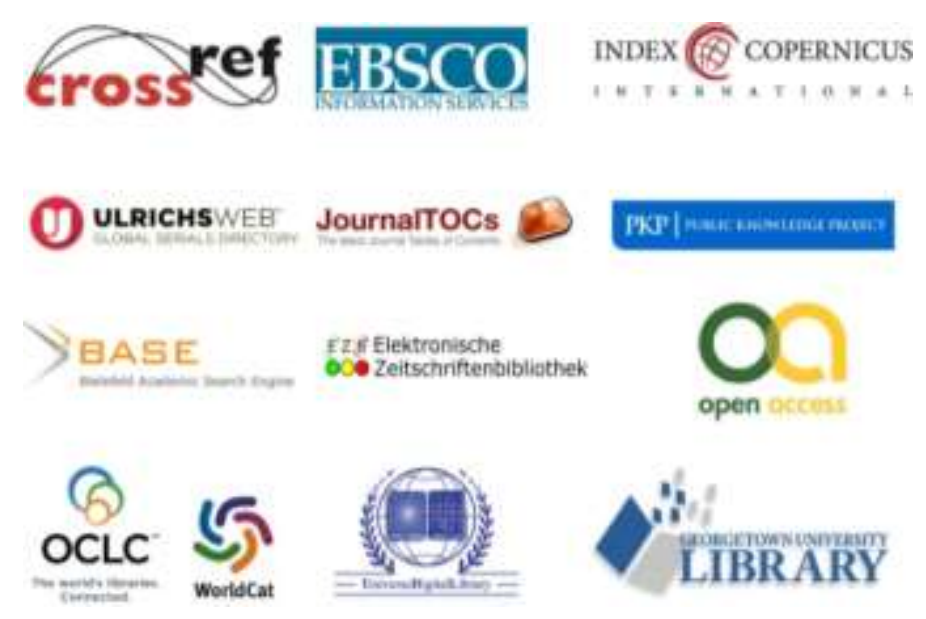

